\title{
Could Demographic Variables Impacting the Relationship Between HRM Practices and Employee Loyalty? A Meta-Analysis Review
}

\author{
AbdulQader Alsaiari \\ Faculty of Administrative Science and Policy Studies \\ Universiti Teknologi MARA, Malaysia \\ E-mail: abdulqadir.sayari@gmail.com
}

Fadilah Puteh

Faculty of Administrative Science and Policy Studies

Universiti Teknologi MARA, Malaysia

E-mail: fadilahputeh@uitm.edu.my

Abdul Jalil Mohamed Ali

Faculty of Administrative Science and Policy Studies

Universiti Teknologi MARA, Malaysia

E-mail: ajali1838@uitm.edu.my

Received: February 23, 2020 Accepted: March 14, 2020 Published: March 17, 2020

doi: 10.5296/hrr.v4i1.16506 URL: https://doi.org/10.5296/hrr.v4i1.16506

\begin{abstract}
This paper aims to ascertain theoretically and empirically if there is any impact of demographic variables on the relationship between HRM best practices and employee loyalty. This paper discussed specific demographic variables namely gender, age, nationality, job experience, and job level. Theoretically, a meta-analysis review was used to cross validated literature review in the area of research. Number of relevant articles derived from several
\end{abstract}




\section{Macrothink}

databases were reviewed to validate the impact. Based on extensive meta-analysis approach, the majority of prior literature illustrated that demographic variables had a significant impact on the relationship between HRM practices and employee loyalty. Previous literatures as well explained that, there are no differences between male and female employee in terms of loyalty, the older employees are more loyal than the younger employees, and the citizens are more loyal than the expatriates. Furthermore, literature pointed that, the longer the employee's years of experience, the more loyalty to the organization as well as the higher the level of the employees' career, the more loyal they have. Empirically, to check the results achieved in meta-analysis review, a quantitative approach was adopted through the questionnaires that were distributed to 52 employees in the largest 14 logistics companies in Oman. Data were analysed using SPSS, as the regression analysis was used to find whether there is any impact of demographic variables on the relationship between HRM practices and employee loyalty. The results illustrated that gender had no impact on the relationship between HRM practices and employee loyalty. While, age, nationality, job experience, and job level had a significant impact on the relationship between HRM practices and employee loyalty. As past studies depicted the impact of demographic variables on HRM practices and employee loyalty, this paper recommends future research to investigate the impact of demographic variables as moderating variables on the relationship between HRM practices and employee loyalty.

Keywords: Demographic variables, HRM practices, Employee loyalty

\section{Introduction}

One of the most important roles and functions of HRM in modern organizations is to make employees loyal to the company and increase their retention. Loyalty is an approach for organizations to establish a solid base with their employees. This is the standard that reveals the true level of performance of an organization. Loyalty-based management aims to give as much attention as possible to employees, and satisfy them in order to increase their loyalty, the sense of job satisfaction and pride for their actions (Klopotan, Buntak, \& Drožđek, 2016). The successful organization that seeks excellence is the one that selects its employees with the intention of retaining them, opens the doors of closed hearts, and works to strengthen the relationship of its employees with their organization (Katou, Budhwar, Woldu, \& Basit Al-Hamadi, 2010).

Employee loyalty is an important factor that active organizations want to gain from their employees. Employee loyalty is related to the level of overall job performance and, therefore; it is one of the key elements in measuring the degree of compatibility between employees on one hand and organizations on the other. The greater the consensus, the more institutions can achieve their goals and aspirations (Hassan, Hassan, Khan, \& Iqbal, 2013). The literature indicates that employee loyalty has interrelated characteristics, as a psychological state that describes the relationship between the employee and the organization, as it possesses a property of influence on employees' decision in relation to their survival or departure (Prabhakar, 2016).

On the other hand, there are number of key issues related to HRM practices that may 
negatively affect employees' performance and productivity, and thus their loyalty to their organization. Some examples of these undesirable HRM practices are discrimination in hiring, lack of recognition, poor employee training, disguised salaries, unfair rewards, lack of financial incentives, bad working environment, and many others. Those such practices may sometimes prompt employees to resign and seek another job (Singh \& Twalo, 2015).

\section{Research Problems and Aims}

In the business environment, demographic factors play a significant role in neutralizing the relationship between HRM and personnel management, which has not been taken into account in previous studies (Klopotan et al., 2016; Buntak \& Drožđek, 2016). As for the demographic factors, they were selected by reference to the previous studies that proved their impact on both HRM practices and employee loyalty. In this research, the demographic variables to investigate the relationship between HRM practices and employee loyalty. Demographic variables (Personal characteristics) are those that distinguish one from another, as these variables may be either individual origins or are related to the work of the individual in the organization. These characteristics include gender, age, nationality, job experience, and job level. The overall relationship between HR management and staff is weakened or strengthened by reference to demographic factors, because men are not as female, the older is not as younger, the employee who has 10 years' experience is not as new and so on. Every employee has a way to increase his/her loyalty to the institution, so the HR department should realize that (Armstrong, Francis, \& Grow, 2017). So this paper comes to ascertain theoretically and empirically if there is any impact of demographic variables on the relationship between HRM best practices and employee loyalty. The objectives of the study are as given below:

- To understand theoretically and empirically if there is any impact of gender on the relationship between HRM best practices and employee loyalty in logistic companies.

- To understand theoretically and empirically if there is any impact of age on the relationship between HRM best practices and employee loyalty in logistic companies.

- To understand theoretically and empirically if there is any impact of nationality on the relationship between HRM best practices and employee loyalty in logistic companies.

To understand theoretically and empirically if there is any impact of job experience on the relationship between HRM best practices and employee loyalty in logistic companies.

To understand theoretically and empirically if there is any impact of job level on the relationship between HRM best practices and employee loyalty in logistic companies.

\section{Employee Loyalty}

There are many views on the concept of employee loyalty. There are those who are viewed from an emotional point of view as the degree of psychological attachment of the employee to the organization through feelings such as belonging and commitment that is the result of that affiliation, as it describes the feelings of the employees and their association with the organization (Buntak \& Drožđek, 2016). Employee loyalty is the most widely used definition 


\section{MInstitute ${ }^{\text {Macrothink }}$}

in studies, since it represents a set of strong positive attitudes towards the organization that are manifested through commitment and adherence to the goals and value of the organization. On the other hand, there are those who view employee loyalty as a continuous state of consciousness based on the interrelationship between the employee and the organization, whereby the individual acquires certain advantages such as security, safety, and tranquillity, and avoids the losses that he or she causes as a result of leaving work (Iqbal, Tufail, \& Lodhi, 2015).

The concept of employee loyalty can be described as the obligation to participate in work, that is, the individual's commitment and support to the organization beyond the expectations of the job and the rewards, as well as the commitment to continue support for the organization regardless of the shifts and changes in feelings and circumstances (Aityan \& Gupta, 2012). For example, the loyalty of an individual may increase when he/she is expected to be rewarded, but this individual is supposed to have loyalty even if it is not rewarded by the organization (Ibrar \& Khan, 2015). Moreover, employee loyalty means the degree of conformity of individuals with their organization as well as their desire to make the greatest effort in favor of the organization in which they work with a strong desire to continue the membership of this organization. This concept is comprehensive and positive, so the relationship must be strong, positive and dynamic. It is also based on internal conviction of the goals or objectives of the organization, not just to evaluate the individual benefits. Emotional bonding is the foundation of employees' loyalty to the organization and reinforces their desire to stay and work (Kee, Low, Ooi, Sam, \& Teng, 2012).

Employee loyalty is a key element in improving the organization's performance. Low employee loyalty leads to a reduction in production rates and contributes to increase employees' behaviors turnover rate and decrease job performance. Even worse, wrong employees' may result from their low loyalty towards organization such as increasing absenteeism and delay, claiming illness to take holidays, doing private works during office time, creating spilt between other employees, and taking extra personal time at work (Kamnerdkarn, 2010). Employee loyalty has a direct relationship with alienation and psychological suffering among employees. In fact, the low loyalty the employee has the more feelings of alienation and psychological suffering and vice versa. As the real challenge for HRM is to create an attractive working environment in the enterprise and deepen employee loyalty (Ibrar \& Khan, 2015).

Employee loyalty is a psychological state that describes the relationship between the employee and the organization. This situation affects the individual's decision to stay or leave the organization. Loyalty results from the interaction of human, organizational and other administrative factors within the organization, such as job satisfaction and organizational climate. It is also an intangible situation, which is evidenced by organizational phenomena that are reflected in the behavior of individuals working in the organization (Kabak et al., 2014). Based on the above, it can be said that there is no uniform definition of employee loyalty. This confirms that it is among concepts that do not have a specific and fixed definition. This is because researchers address this concept from the angle of the field to which they belong, which led them to construct their own definitions, and thus their 


\section{$\triangle$ Macrothink}

measurements, which were designed on the basis of these definitions (Khuong \& Tien, 2013).

The concept of loyalty has long been concerned with the interest of researchers both in the field of psychology and sociology for a long time, but not enough attention was given to management until after the emergence of a behavioral school that emphasized the importance of human relations in organizations (Vinayan, 2015). Moreover, researches have shown that employee loyalty is a key element in improving the organization's performance. Low employee loyalty leads to a reduction in production rates and contributes to increase employees' turnover rate and decrease job performance. In contrast, high employee loyalty leads to an increase in productivity, performance, and profitability (Tomic, Tesic, Kuzmanovic, \& Tomic, 2018). Even worse, bad employee behavior such as increasing absenteeism and delay, claiming illness to take holidays, doing private works during office time, creating spilt between other employees, and taking extra personal time at work, may result from low employee loyalty (Klopotan et al., 2016; Katou et al., 2010). Loyalty has a direct relationship with alienation and psychological suffering among employees. In fact, the low loyalty the employee has the more feelings of alienation and psychological suffering and vice versa. As a result of all what has been mentioned, the real challenge for HRM is to create an attractive working environment in the enterprise and deepen employee loyalty (Maimako \& Bambale, 2016).

\section{HRM Practices}

The philosophy of HRM has evolved steadily based on the shift in business environment. The traditional view of HR has been based on the physiological structure of individuals, their muscular strength, and the mechanism of their performance. While modern thinking has been concerned with the individual's mental capacity, and intellectual and creative energy. This development has led to a change in the role of HRM in the Organization, from its traditional role of recruiting, paying wages, and granting leave to its strategic role, which requires the availability of specialized competencies and the construction of long-term plans (Alfes, Shantz, Truss, \& Soane, 2013). The human element forms the basis and essence of HRM. It holds values for the organization. Therefore, the human element is one of the most important resources owned by the organization, so they sought to take care of its employees, develop their skills, and improve their efficiency, so that the organization can achieve its goals efficiently and effectively and face rapid changes in its environment, whether internal or external (Armstrong \& Taylor, 2014).

HR Department has two basic functions that are administrative and specialized. In administrative function, HR department participates with other administrative units in the organization in planning, organizing, directing, supervising, innovating, developing, and allocating resources. On the other hand, specialized function focuses on HR practices, including HR development and training, HR compensation, HR labor relations, HR performance assessment, and HR safety and care.

When these practices are used in organizations of any size, the process of achieving the objectives of the organization will be easy, by linking the functions of each other, so that there is a result and the existence of succession from one job to another through the reality 
lists of required practices (Kehoe \& Wright, 2013).Based on the above, HRM practices can be defined as a set of practices developed to provide and coordinate human elements in organizations in order to achieve higher productivity (Vanhala and Ritala, 2016). According to Armstrong and Taylor (2014), HRM Practices can be categorized into three (3) main practices namely:

1) Specialized practices, which are carried out by HRM within the organization, as the number of these practices varies from one organization to another according to the philosophy of senior management, the size of the organization, the type of technology used, the characteristics of the labor market, and the efficiency and skill of its employees. The most important of these practices are namely job classification, HR planning, recruitment, determining compensation that suits the job requirements, as well as Identification, design, implementation and follow-up of training and development programs, monitoring and evaluation of the work environment for the purpose of achieving occupational health and safety in the workplace and raising the morale of staff.

2) Managerial practices, which are required by HR Department to carry out its business and specialized functions, which it requires to provide other departments with all its human resources requirements in terms of preparation and specialization appropriate to the nature of their work. Deficiencies in the assessment of human resource needs, selection, appointment, training, or motivating staff impair the work of these departments, and hence the objectives of the organization cannot be achieved.

3) Consultative practices, which is to provide advice to employees and to all the departments operating in the Organization, both technically and legally, in addition to proposing improvements and developing instructions and regulations related to employees from wages, incentives, services, working conditions, etc. This requires that HRM be more relevant and more responsive to the other departments of the organization, more informed about its problems, and deeper cooperation and understanding of its diverse affairs so that it can perform its advisory role as required.

Hence, it is found that there is agreement that HRM is one of the basic functions in organizations and responsible for everything related to the human element before entering the organization through employees search, recruitment, selection and appointment, during their work through training and motivation, and after their leaving the organization through the procedures of their dismissal and the payment of their compensation (Brewster et al., 2016). The importance of HRM in logistics organizations is the responsibility for the most important element of production, which is the human element, as if it properly built, it becomes a competitive advantage that is difficult to imitate. Some writers contribute to the enumeration of specialized HRM functions and others integrate them, but they do not exceed the function of human resources planning, polarization, selection, appointment, compensation, training and development, and evaluation of the performance of employees (Schlechter, Thompson, \& Bussin, 2015).

It can be said that the ability of organizations to achieve their goals depends to a large extent on the success of HRM department in providing sufficient motivation for employees, which 


\section{Macrothink}

in turn drives employees to production and creativity, which makes them feel satisfied, which contributes to increase their loyalty to the institution they work, as the employee feels that he/she is an integral part of this organization (Alshuaibia \& Shamsudinb, 2016). If HRM can reach those concepts to the employees, it will have put its hand on the biggest incentive for them. Any organization always wants to raise the loyalty and belonging of its employees. This loyalty and belonging are a kind of organizational citizenship, which will not be achieved by slogans and banners, but may be achieved through incentives provided to the employees, which raises their organizational citizenship and loyalty to the organization (Schlechter et al., 2015). There is a fine line between keeping a promise and breaking a promise that determine the survival or departure of staff. When management keeps its promises, this will make it trust and respect, as this is one of the most important qualities of management. But when the administration ignores its obligations, it means indifference, disrespect and appreciation to its employees, weakening their loyalty to the organization (Singh \& Kassa, 2016).

Some research has been conducted by a number of authors on logistics sector such as Wallenburg et al. (2010), who examined how goal achievement influences the aspects of loyalty in logistics outsourcing relationships. Also, Sila and Širok (2018) illustrated the importance of employee satisfaction and loyalty in the transportation and logistics service industry. Furthermore, Menon (2012) identified HRM practices that affect employee loyalty in organization's supply chain, as the results showed that HRM practices such as training and rewards leads to increase employee loyalty. According to Chyn and Kaliannan (2011), one of the major problems faced by logistic companies is high turnover rate, especially among the drivers.

\section{The Impact of Demographic Variables on HRM Practices and Employee Loyalty}

Personal characteristics (demographic variables) are those that distinguish one from another, as these variables may be either individual origins or are related to the work of the individual in the organization. These characteristics include gender, age, nationality, job experience, and job level. In addition, Klopotan et al. (2016) illustrated that the individual becomes linked to the organization as a result of the multiple interactions in the organization, which have accumulated over the years, since it expresses a person's beliefs and tendencies towards the organization, so that such behaviour becomes binding on the individual later.

There is much controversy about the impact that demographic variables have on the relationship between HRM practices and employee loyalty. All HRM practices and policies are based on the scientific means by which to choose the best elements to do the work, and then create all the possible conditions for them to do their best to reduce problem associated with demographic issues, thereby achieving employee satisfaction and loyalty (Hassan et al., 2013). In addition, Shonubi, Abdullah, Hashim and Ab Hamid (2016) illustrated that HRM department should be fair in showing appreciation to their employees, whether male or female, older or younger, and citizens or expat, so it should be careful not to create confusion among its employees by establishing a clear policy of appreciation for employees, clarifying the reasons for employee achievement. 


\section{Macrothink}

Successful HRM is able to gain collective support for the achievement of work, regardless of any differences in demographic characteristics, through the development of employee skills using reward systems. It is the activity that management exercises to influence the behaviour of others to motivate them to cooperate and achieve the goals. This is also the art of being able to influence and guide employees in a way that leads to their satisfaction, loyalty and cooperation to reach the goals without resorting to traditional means of oppression and apostasy (Schlechter et al., 2015). HRM practices that takes into account demographic characteristics are a key part of the management process that seeks to achieve specific goals efficiently and effectively, thus increasing the loyalty of all employees (Hon, Chan, \& Lu, 2013).

According to semi-structured interviews with 260 current and former public employees conducted by Swailes and Al Fahdi (2011), participants regardless of their gender and age revealed concerns about the lack of praise or recognition, as interviewees believe that they do not receive enough support from HRM department, whether material or moral support, or even at least a word of thanks. They said that this affects their morale, and therefore their loyalty, as $77 \%$ are looking for another job, also, some stressed that HRM department is interested only in getting closer to the senior management, and never cares about the problems of employees. Furthermore, Kaufman, Chapman and Allen (2013) attempted to identify employee loyalty and its relation to recognition among employees in factories, as they concluded that there was a statistically significant relationship between employee loyalty and employee recognition, and that there were differences in the level of loyalty due to gender, age, and length of service. In addition, employees in logistics companies in Oman, like other employees in other companies, need a certain level of incentives, both material and moral, to raise the level of performance and motivate them to make maximum effort, which would increase their loyalty to the companies at which they work (Al Saddi, 2016). The importance and nature of incentives vary from individual to individual depending on gender, age, job level, and job experience (Vinayan, 2015). According to statistics posted by Y Magazine in 2017, it was revealed that nearly 55 percent of Omanis working, with both sexes, different ages, and diverse experiences in the private sector receive a very low income which does not lead to a dignified life. In addition to the complete absence of any kind of incentives, whether material or moral (Jureidini, 2016). It also found that despite the long service of some employees in logistics companies, which exceeded 20 years, they did not get appropriate promotion (Porkodi \& Jahan, 2015). According to the annual report of the Ministry of Manpower-Oman, it was found that the number of employees resigned in the private sector in Oman reached 34006, as the number of males was 21391, while females 12615. The report also showed that males who have certificate less than the general high school education were the most resigned (11640), followed by males who hold the high school education (6150), while the males with university diploma had the least resignations (1514). In addition, the results showed that the females who hold the general high School education was the most resigned (5977), followed by females who have less than a general High school education (4410), while females with university degree has the least resignations (818). Regarding the skills level, the report indicated that both males and females with less technical skills were the most resigned, followed by those with semi skills, while those with 
specialized skills had the least resignations. Regarding age group, the age group between 25 and 39, for both males and females, had the most resignations.

\subsection{Gender}

Gender is an important factor that is dealt with in the field of employee loyalty in order to identify the nature of the relationship between gender and employee loyalty. It is impossible to ignore the nature of the employee's gender in the work environment, because of the different psychological and mental composition of male and female (Buntak \& Drožđek, 2016). Female employees were more loyal than male employees, as the reason is attributed to the fact that women's opportunities for employment in other organizations are less than men's, and therefore are trying to do a good job in their organization (Kato and Kodama, 2017; Klopotan et al, 2016). On the other hand, some studies indicated that there were no differences between males and females in loyalty (Al-Belushi \& Khanm 2017). This may be due to the lack of differentiation in the privileges between males and females, and the great opportunities for all, so it did not affect their loyalty (Pandey \& Khare, 2012).

Various HRM practices that are conducted by organizations should reduce the gender gap. Ismail and Nakkache (2015) explained that HRM practices sometimes represent a breach of the concept of equality par excellence, manifested through behaviours lined in appointment and promotion, as ignoring the work done by female employees and lacking recognition and appreciation in the long run leaves them with a disappointment, as well as the sense that HRM do not care about their presence or not. In addition, Pandey and Khare (2012) explained that there was a significant gender differences according to HRM practices including recognition, support, and training.

Maintaining an ideal work environment requires equal rights and duties between male and female by HRM, so that one party does not defect to the other, causing internal conflicts and problems that reduce employee performance and force some to quit work and go to competing companies (Kato \& Kodama, 2017). In other words, gender discrimination is a major reason for poor employee productivity and minimizing their loyalty to the organization in which they work (Ismail \& Nakkache, 2015). Pandey and Khare (2012) also HRM to establish justice and treat women like men, as promotion, incentives and rewards are based on diligence and job evaluation.

\subsection{Age}

Many studies have confirmed that there is a positive relationship between age and employee loyalty, so that the higher the employee's age, the higher the level of loyalty he/she has (Klopotan et al., 2016). This is because he/she becomes more convinced, functional, and realistic than before, in addition to the lack of alternatives available to him/her to move to other organizations (Pandey \& Khare, 2012). Furthermore, Nisar, Uzair, Razzaq and Sarfraz (2017) pointed out that there is a positive correlation between employee loyalty and age in private institutions, especially if there is an increase in salaries and wages. In addition, Geevarghese, Nirmalraj, Seeram, Veena and James (2018) concluded that people who are older show statistically significant higher organizational loyalty than those who are younger. 
HRM practices should take age differences into account, including recognition, compensation, promotion, and training, as understanding the desires and needs of older and younger employees can be helpful in increase their loyalty (Kooij, Guest, Clinton, Knight, Jansen, \& Dikkers, 2013). Also, Truxillo, Cadiz and Rineer (2014) stressed that HRM practices might change with age because the desires and needs of older employees differ from the younger employees, therefore, addressing issues related to age differences by HRM department is the way to create an ideal work environment.

The relationship between employee loyalty and age is not a direct linear relationship, since increasing the age of the employee does not necessarily correspond to increasing job loyalty, which requires determinants and other factors. For instance, Ineson, Benke and László (2013) pointed out those levels of loyalty decreases as the employee progresses in age. This is due to the availability of many alternatives to those who acquire job experience and flexibility in the labour market to move to another employer. In addition, efficiency and privileges are not calculated by age, but by other standards in those organizations).

\subsection{Nationality}

Nationality variable is important in determining the level of loyalty among employees. Some researchers have called for the need to discuss the individual differences between local and expat employees as well as analyse the implications of these differences on employee loyalty in the presence of many nationalities in the Gulf work environment (Ibrahim \& Al Falasi, 2014). In addition, Armstrong et al. (2017) illustrated that local citizens were the most loyal, while expatriates are the most unfair in regard to the promotion and incentives.

Best HRM practices mean that there is fairness in rewards and incentives regardless of the nationalities or cultures of employees, where performance and achievements must be the measure that is taken into account when evaluating the performance of employees, in this case, employees will view the organization with respect and appreciation, which increases their loyalty to the job (Alfes et al., 2013). Moreover, Sekyi Boakye and Ankumah (2016) indicated that there was significant relationship between HRM practices and nationality, as they noted the importance of defining and formulating the efficient laws and regulation that serve all employees, which improve their performance. Furthermore, Ahammad (2017) explained that nationality have positive significant relationships with HRM practices, as the appreciation of employees of different nationalities contributes to increasing their loyalty.

Moreover, many studies have shown that HRM practices a form of hate, hostility and intensity in dealing with expat employees, taking advantage of their need to work. Also, many expat employees do not like to enter into problems with HRM in order to continue working and ensure that they obtain new contracts (Armstrong et al. 2017). From here, HRM must ensure fair treatment for all employees in terms of salaries, bonuses, vacations, distribution of work, and promotion, which helps to improve their performance and increase their loyalty, which benefits the organization as a whole (Ibrahim \& Al Falasi, 2014). 


\subsection{Job Experience}

Job experience is one of the reasons for employee loyalty, which in fact reflects the importance of social normalization in the process of employee loyalty, as the impact of the job experience on employee loyalty increases with the length of service in the organization, which necessitates attention to social normalization programs aimed at linking the individual organization that works since the first year of joining instead of relying on the long service factor to obtain employee loyalty (Hill \& Alexander, 2017).

Some studies have shown that there is a positive relationship between experience and employee loyalty; as the longer the employee's years of experience, the more loyalty to the organization. Many studies have attributed this to the social interaction between the employee and the co-workers on the one hand, and the employee and direct leadership on the other hand. The fellowship in work and social relations that the employee has with his or her co-workers, both within and outside the workplace, increases with the individual's investment of time and effort, leading to a psychological connection with the organization (Ibrar \& Khan, 2015). As time goes by, an individual's experience of work performance increases with his/her aging in the workplace, helping to acquire new ways and methods to deal with co-workers, thereby increasing his/her loyalty to the organization. Also, the high availability of opportunities for the employee to get a promotion at work, as well as the possibility of achieving some of the privileges, whether, moral or physical contribute to increase loyalty to the organization (Hill \& Alexander, 2017).

Several studies discussed the relationship between HRM practices and job experience as in the study of Mira, Choong and Thim (2019), which indicated that highly experienced employees should receive recognition from HRM Department through remunerative rewards and privileges, however, employees with little experience should be given more training and attention, which increases their loyalty to the organization in which they work, which is in the interest of the organization. Moreover, Fairlie and Miranda (2017) stressed the strict adherence to all stages of the promotion process in line with employee experience, due to the vital role played by HRM in achieving the objectives of the organization. Furthermore, Donovan, Dwight and Schneider (2014) explained that best HRM practices could handle with job experience using the correct scientific procedures for the selection process and promotion to raise the level of performance of employees, and thus reflect on their loyalty.

New employees often have less age and job experience than their older colleagues, and this naturally generates an impact on employee loyalty, as new employees less loyal to their organization than their peers (Ibrar \& Khan, 2015). The reason may be due to their lack of full knowledge of the organization, its objectives and policy. When the individual's years of service in the organization increase, his/her chances are greater in obtaining moral rewards such as career advancement to a higher-level job, attention, personal appreciation, and independence at work. As the individual reacts socially and has many relationships and friendships with colleagues and bosses at work. In contrast, other studies have shown that there is no relationship between years of service and employee loyalty, as the reason is that 
promotions and privileges are based on criteria other than years of service in some organizations (Kathure, 2014).

\subsection{Job Level}

HRM should assign employees to an entry-level position that suits and provides them with opportunities for achievement, growth and development in a reasonable manner. Job level is mixed with motivation, ambitions, and personal characteristics. Employees with the greatest need for self-affirmation are willing to work with a kind of challenge and a certain degree of difficulty. While individuals characterized by a lack of ambition or lack of desire to learn and develop, they prefer routine work, so job level and responsibilities have a vital role in influencing the degree of loyalty. In addition, job level is one of the most important administrative tasks that HRM department may make, as best HRM practices are complemented by the completion of a range of activities which are polarization, selection and appointment (Sekyi et al., 2016). Therefore, it can be said that outcomes of HRM practices must be the application of the principle of putting the right person in the right place at the right time. Moreover, best HRM practices include a good distribution of responsibilities and duties as needed, regardless of personal considerations, which may cause disputes and differences, which reduces employee loyalty (Hassan, 2016).

Furthermore, Harrison (2013) has shown that there was a positive relationship between employee loyalty and job level. The higher the level of the individuals' career, the more loyal they have, because they have made too much effort in order to reach that position, making it difficult for them to leave and sacrifice. In contrast, the study found the opposite result (a negative relationship between employee loyalty and job level). At a high job level, the employee has discovered criteria that may not be objective, especially regarding the system of promotion and distribution of bonuses, which reflects negatively on the degree of association and orientation towards the organization.

Most of the previous studies dealt with the effect of demographic factors on the relationship between HRM practices and employee loyalty, since studies differed clearly in determining the importance of demographic factors and their role in this relationship. For instance, Pandey and Khare (2012) claimed that employee loyalty increases with age, while, Ineson et al. (2013) pointed out that employee loyalty decreases with age. Also, Al-Belushi and Khan (2017) said that women loyalty higher than men loyalty. Furthermore, Ibrahim and Al Falasi (2014) illustrated that the original citizen has more loyalty than the expatriate. Moreover, Ibrar and Khan (2015) claimed that the longer the employee's years of experience, the more loyalty to the organization. In addition, Harrison (2013) explained that employee loyalty increases with high job level. Therefore, the researcher agrees with previous studies regarding age, gender, nationality, and job level. However, the researcher disagrees with previous studies regarding job experience, sometimes the more the employee experiences, the more opportunities he/she will have to work, which may leave him/her to work and look for another challenge, especially if the new job has better privileges in terms of salary, incentives, promotion, etc. 


\section{Macrothink}

The Table 1 lists the various relevant research literatures available in relation to demographic variables in order to clarify the relationship between HRM practices and employee loyalty.

Table 1. Meta-analysis on demographic variables

\begin{tabular}{|c|c|c|c|c|}
\hline $\begin{array}{l}\text { Author(s) \& } \\
\text { Year }\end{array}$ & $\begin{array}{l}\text { Objective/ } \\
\text { Research } \\
\text { Questions }\end{array}$ & $\begin{array}{l}\text { Country, } \\
\text { Research } \\
\text { context, } \\
\text { sample size, } \\
\text { Analysis } \\
\text { technique } \\
\text { (Methods) }\end{array}$ & $\begin{array}{l}\text { Variables } \\
\text { studied in } \\
\text { the article }\end{array}$ & $\begin{array}{l}\text { Main findings of } \\
\text { the study }\end{array}$ \\
\hline $\begin{array}{l}\text { Mira et al. } \\
(2019)\end{array}$ & $\begin{array}{l}\text { To discuss the } \\
\text { relationship } \\
\text { between HRM } \\
\text { practices and job } \\
\text { experience. }\end{array}$ & $\begin{array}{l}\text { The } \\
\text { questionnaires } \\
\text { distributed } \\
\text { among } 367 \text { of } \\
\text { cargo } \\
\text { employees in } \\
\text { SPA under the } \\
\text { Saudi } \\
\text { Government. }\end{array}$ & $\begin{array}{l}\text { Job } \\
\text { Experience, } \\
\text { HRM } \\
\text { Practices, } \\
\text { Employee } \\
\text { Loyalty. }\end{array}$ & $\begin{array}{l}\text { Highly experienced } \\
\text { employees should } \\
\text { receive recognition, } \\
\text { rewards } \\
\text { privileges, while } \\
\text { employees with } \\
\text { little experience } \\
\text { should be given } \\
\text { more training and } \\
\text { attention, which } \\
\text { increases their } \\
\text { loyalty. }\end{array}$ \\
\hline $\begin{array}{l}\text { Strenitzerová } \\
\text { and Achimský } \\
\text { (2019) }\end{array}$ & $\begin{array}{l}\text { To identify job } \\
\text { attributes and } \\
\text { socio-demographi } \\
\text { c characteristics } \\
\text { affecting } \\
\text { employee } \\
\text { satisfaction and } \\
\text { loyalty as a key } \\
\text { concern for } \\
\text { sustainable human } \\
\text { resource } \\
\text { management. }\end{array}$ & $\begin{array}{l}1775 \quad \text { survey } \\
\text { questionnaires } \\
\text { of employees } \\
\text { in Slovak } \\
\text { Postal } \\
\text { enterprise. }\end{array}$ & $\begin{array}{l}\text { Age, } \\
\text { Job } \\
\text { Experience, } \\
\text { Job Level, } \\
\text { Employee } \\
\text { Loyalty. }\end{array}$ & $\begin{array}{l}\text { The age of the } \\
\text { employee, the job } \\
\text { position and the } \\
\text { length } \\
\text { employment have a } \\
\text { strong influence on } \\
\text { employee loyalty. }\end{array}$ \\
\hline $\begin{array}{l}\text { Geevarghese } \\
\text { et al. (2018) }\end{array}$ & $\begin{array}{l}\text { To investigate the } \\
\text { effect of age of } \\
\text { employee on } \\
\text { employees' } \\
\text { loyalty in a }\end{array}$ & $\begin{array}{l}\text { Survey was } \\
\text { conducted with } \\
\text { a standardized, } \\
\text { valid and } \\
\text { reliable }\end{array}$ & $\begin{array}{l}\text { Age, } \\
\text { Employee } \\
\text { Loyalty. }\end{array}$ & $\begin{array}{l}\text { People who are } \\
\text { older show } \\
\text { statistically } \\
\text { significant higher } \\
\text { organizational }\end{array}$ \\
\hline
\end{tabular}




\begin{tabular}{|c|c|c|c|c|}
\hline & $\begin{array}{l}\text { Bangalore based } \\
\text { large-scale } \\
\text { public-sector } \\
\text { undertaking. }\end{array}$ & $\begin{array}{l}\text { instrument } \\
\text { measuring } \\
\text { loyalty. }\end{array}$ & & $\begin{array}{l}\text { loyalty than those } \\
\text { who are younger. }\end{array}$ \\
\hline $\begin{array}{l}\text { Abidi, Halil, } \\
\text { Youssef, } \\
\text { Habibniya and } \\
\text { Baran (2017) }\end{array}$ & $\begin{array}{l}\text { To reveal the } \\
\text { effect of diversity } \\
\text { management } \\
\text { implementation in } \\
\text { Kuwaiti } \\
\text { companies on } \\
\text { HRM practices. }\end{array}$ & $\begin{array}{l}\text { The } \\
\text { questionnaires } \\
\text { distributed } \\
\text { among } \quad 354 \\
\text { useful ones } \\
\text { from } \\
\text { different } \\
\text { companies. }\end{array}$ & $\begin{array}{l}\text { Nationality, } \\
\text { HRM } \\
\text { Practices. }\end{array}$ & $\begin{array}{l}\text { Employees from } \\
\text { different cultures } \\
\text { have the most } \\
\text { significant effect on } \\
\text { HRM practices. }\end{array}$ \\
\hline $\begin{array}{l}\text { Armstrong et } \\
\text { al. (2017) }\end{array}$ & $\begin{array}{l}\text { To the } \\
\text { understanding of } \\
\text { ethical factors } \\
\text { regarding local } \\
\text { and expat } \\
\text { employees and its } \\
\text { impact on } \\
\text { employee loyalty. }\end{array}$ & $\begin{array}{l}\text { The } \\
\text { methodology } \\
\text { was a survey of } \\
500 \text { hospitality } \\
\text { industry } \\
\text { employees. }\end{array}$ & $\begin{array}{l}\text { Nationality, } \\
\text { Employee } \\
\text { Loyalty. }\end{array}$ & $\begin{array}{l}\text { Local citizens the } \\
\text { most loyal, while } \\
\text { expatriates are the } \\
\text { most unfair in } \\
\text { regard to the } \\
\text { promotion and } \\
\text { incentives. }\end{array}$ \\
\hline $\begin{array}{l}\text { Nisar et al. } \\
(2017)\end{array}$ & $\begin{array}{l}\text { To examine the } \\
\text { relationship } \\
\text { between } \\
\text { Practices, loyalty } \\
\text { and commitment } \\
\text { with mediating } \\
\text { role of job } \\
\text { satisfaction in } \\
\text { banks of } \\
\text { Gujranwala } \\
\text { Pakistan. }\end{array}$ & $\begin{array}{l}\text { Survey } \\
\text { questionnaire } \\
\text { method is used } \\
\text { for the purpose } \\
\text { of data } \\
\text { collection. }\end{array}$ & $\begin{array}{l}\text { Training, } \\
\text { Compensati } \\
\text { on, } \\
\text { Age, } \\
\text { Employee } \\
\text { Loyalty. }\end{array}$ & $\begin{array}{l}\text { - Results revealed } \\
\text { that HR practices } \\
\text { are significantly } \\
\text { and positively } \\
\text { related to employee } \\
\text { loyalty. } \\
\text { - Employee loyalty } \\
\text { increases with age. }\end{array}$ \\
\hline $\begin{array}{l}\text { Al-Belushi } \\
\text { and Khan } \\
(2017)\end{array}$ & $\begin{array}{l}\text { To investigate the } \\
\text { impact of } \\
\text { monetary } \\
\text { incentives on the } \\
\text { employee loyalty. }\end{array}$ & $\begin{array}{l}\text { The study } \\
\text { included } \\
\text { samples of } 130 \\
\text { employees } \\
\text { from all the } \\
\text { academic and } \\
\text { non-academic } \\
\text { staff of the } \\
\text { college } \\
\text { collected } \\
\text { through }\end{array}$ & $\begin{array}{l}\text { Compensati } \\
\text { on, } \\
\text { Gender, } \\
\text { Employee } \\
\text { Loyalty. }\end{array}$ & $\begin{array}{l}\text { - Monetary } \\
\text { incentives have a } \\
\text { direct impact on } \\
\text { employee loyalty. } \\
\text { - Women loyalty } \\
\text { higher than men } \\
\text { loyalty. }\end{array}$ \\
\hline
\end{tabular}




\begin{tabular}{|c|c|c|c|c|}
\hline & & $\begin{array}{l}\text { a well-defined } \\
\text { questionnaire. }\end{array}$ & & \\
\hline $\begin{array}{l}\text { Marcus and } \\
\text { Gopinath } \\
\text { (2017). }\end{array}$ & $\begin{array}{l}\text { To understand the } \\
\text { impact of the } \\
\text { demographic } \\
\text { variables on } \\
\text { employee } \\
\text { engagement, and } \\
\text { therefore } \\
\text { employee loyalty. }\end{array}$ & $\begin{array}{l}\text { The data was } \\
\text { collected from } \\
600 \\
\text { respondents } \\
\text { from } 33 \text { IT } \\
\text { companies } \\
\text { located in } \\
\text { South } \\
\text { Chennai. }\end{array}$ & $\begin{array}{l}\text { Gender, } \\
\text { Age, } \\
\text { Employee } \\
\text { Engagement. } \\
\text { Employee } \\
\text { Loyalty. }\end{array}$ & $\begin{array}{l}\text { - The age has an } \\
\text { influence on } \\
\text { employee } \\
\text { engagement, and } \\
\text { therefore employee } \\
\text { loyalty. } \\
\text { - Gender has no } \\
\text { impact } \\
\text { employee } \\
\text { engagement, and } \\
\text { therefore employee } \\
\text { loyalty. }\end{array}$ \\
\hline $\begin{array}{l}\text { Buntak and } \\
\text { Drožđek } \\
(2016) .\end{array}$ & $\begin{array}{l}\text { To test the } \\
\text { important } \\
\text { parameters of the } \\
\text { loyalty of } \\
\text { employees in the } \\
\text { public and private } \\
\text { sectors. }\end{array}$ & $\begin{array}{l}50 \\
\text { questionnaires } \\
\text { distributed in } \\
\text { each sector. }\end{array}$ & $\begin{array}{l}\text { Rewards, } \\
\text { Working } \\
\text { Environment } \\
\text { ' Gender, } \\
\text { Age, } \\
\text { Employee } \\
\text { Loyalty. }\end{array}$ & $\begin{array}{l}\text { There is a } \\
\text { difference in } \\
\text { valuation of the key } \\
\text { parameters of } \\
\text { employee loyalty of } \\
\text { employees } \\
\text { according to sex, } \\
\text { age, level of } \\
\text { education. }\end{array}$ \\
\hline $\begin{array}{l}\text { Kossivi, Xu } \\
\text { and Kalgora } \\
(2016)\end{array}$ & $\begin{array}{l}\text { To look at the } \\
\text { following broad } \\
\text { factors: } \\
\text { development } \\
\text { opportunities, } \\
\text { compensation, } \\
\text { work } \\
\text { environment, } \\
\text { training and } \\
\text { development. }\end{array}$ & $\begin{array}{l}\text { The findings of } \\
\text { previous } \\
\text { studies. }\end{array}$ & $\begin{array}{l}\text { Job } \\
\text { Experience, } \\
\text { Compensati } \\
\text { on, Work } \\
\text { Environment } \\
, \quad \text { Training, } \\
\text { Employee } \\
\text { Retention } \\
\text { And } \\
\text { Loyalty. }\end{array}$ & $\begin{array}{l}\text { The greater the job } \\
\text { experience, the } \\
\text { greater their loyalty } \\
\text { to the institution. }\end{array}$ \\
\hline $\begin{array}{l}\text { Klopotan et } \\
\text { al. (2016) }\end{array}$ & $\begin{array}{l}\text { To define whether } \\
\text { there is a } \\
\text { difference in } \\
\text { parameters of } \\
\text { employee loyalty } \\
\text { of employees in } \\
\text { the public and the } \\
\text { private sector in } \\
\text { Croatia. }\end{array}$ & $\begin{array}{l}\text { A questionnaire } \\
\text { was distributed } \\
\text { among } 50 \\
\text { respondents in } \\
\text { each sector. }\end{array}$ & $\begin{array}{l}\text { Age, } \\
\text { Gender, } \\
\text { Employee } \\
\text { Loyalty. }\end{array}$ & $\begin{array}{l}\text { There are a few } \\
\text { parameters } \\
\text { employee loyalty } \\
\text { dependent } \\
\text { education, gender } \\
\text { and age, and the } \\
\text { sector } \\
\text { employment. }\end{array}$ \\
\hline
\end{tabular}




\begin{tabular}{|c|c|c|c|c|}
\hline $\begin{array}{l}\text { Vinayan } \\
\text { (2015). }\end{array}$ & $\begin{array}{lr}\text { To propose a } \\
\text { research agenda } \\
\text { in ethical } \\
\text { practices } \\
\text { increase employee } \\
\text { loyalty. }\end{array}$ & $\begin{array}{l}\text { This paper } \\
\text { collates from } \\
\text { literature, } \\
\text { regarding HRM } \\
\text { practices and } \\
\text { employee } \\
\text { loyalty. }\end{array}$ & $\begin{array}{l}\text { Hrm } \\
\text { Practices, } \\
\text { Employee } \\
\text { Loyalty, } \\
\text { Gender, } \\
\text { Age, Job } \\
\text { Level, Job } \\
\text { Experience }\end{array}$ & $\begin{array}{l}\text { There was a large } \\
\text { impact of HRM } \\
\text { practices } \\
\text { employee loyalty, } \\
\text { depending } \\
\text { gender, age, job } \\
\text { level, and job } \\
\text { experience. }\end{array}$ \\
\hline $\begin{array}{l}\text { Ismail and } \\
\text { Nakkache } \\
(2015)\end{array}$ & $\begin{array}{l}\text { To explore gender } \\
\text { differences in } \\
\text { HRM practices } \\
\text { policies in the } \\
\text { workplace. }\end{array}$ & $\begin{array}{l}\text { A questionnaire } \\
\text { was distributed } \\
\text { among } 100 \\
\text { participants in } \\
\text { the country of } \\
\text { Lebanon. }\end{array}$ & $\begin{array}{l}\text { Gender, } \\
\text { HRM } \\
\text { Practices }\end{array}$ & $\begin{array}{l}\text { There was a } \\
\text { significant gender } \\
\text { differences } \\
\text { according to HRM } \\
\text { practices including } \\
\text { recognition and } \\
\text { training. }\end{array}$ \\
\hline $\begin{array}{l}\text { Truxillo et al. } \\
\text { (2014) }\end{array}$ & $\begin{array}{l}\text { To examine the } \\
\text { implications of } \\
\text { age differences on } \\
\text { HRM practices. }\end{array}$ & $\begin{array}{l}\text { Reviewing } \\
\text { research and } \\
\text { theories } \\
\text { relevant to } \\
\text { understand in } \\
\text { age-related } \\
\text { changes at } \\
\text { work. }\end{array}$ & $\begin{array}{l}\text { Age, HRM } \\
\text { Practices }\end{array}$ & $\begin{array}{l}\text { HRM practices } \\
\text { might change with } \\
\text { age because the } \\
\text { desires and needs } \\
\text { of older employees } \\
\text { differ from the } \\
\text { younger } \\
\text { employees. }\end{array}$ \\
\hline $\begin{array}{lr}\text { Ibrahim } & \text { and } \\
\text { Al } & \text { Falasi } \\
(2014) & \end{array}$ & $\begin{array}{l}\text { To investigate the } \\
\text { relationship } \\
\text { between } \\
\text { employee loyalty } \\
\text { and its two } \\
\text { dimensions } \\
\text { namely, affective } \\
\text { commitment and } \\
\text { continuance } \\
\text { commitment with } \\
\text { employee } \\
\text { engagement. }\end{array}$ & $\begin{array}{l}\text { A } \\
\text { self-administer } \\
\text { ed } \\
\text { questionnaire } \\
\text { was used for } \\
\text { collecting the } \\
\text { study data from } \\
50 \text { employees. }\end{array}$ & $\begin{array}{l}\text { Nationality, } \\
\text { Employee } \\
\text { Loyalty. }\end{array}$ & $\begin{array}{l}\text { Local employees } \\
\text { were more loyalty } \\
\text { than expat } \\
\text { employees. }\end{array}$ \\
\hline $\begin{array}{l}\text { Waqas, } \\
\text { Bashir, Sattar, } \\
\text { Abdullah, } \\
\text { Hussain, } \\
\text { Anjum and } \\
\text { Arshad (2014) }\end{array}$ & $\begin{array}{l}\text { To find the job } \\
\text { level, and its } \\
\text { impact on loyalty } \\
\text { to help HRM } \\
\text { system. }\end{array}$ & $\begin{array}{l}\text { Questionnaire } \\
\text { was developed } \\
\text { to collect the } \\
\text { data. }\end{array}$ & $\begin{array}{l}\text { Job Level, } \\
\text { Employee } \\
\text { Loyalty. }\end{array}$ & $\begin{array}{l}\text { There was a } \\
\text { positive } \\
\text { relationship } \\
\text { between employee } \\
\text { loyalty and job } \\
\text { level. }\end{array}$ \\
\hline
\end{tabular}




\begin{tabular}{|c|c|c|c|c|}
\hline $\begin{array}{l}\text { Yaghi and } \\
\text { Aljaidi (2014) }\end{array}$ & $\begin{array}{l}\text { To examine the } \\
\text { relationship } \\
\text { between } \\
\text { employees' } \\
\text { nationality and } \\
\text { their commitment } \\
\text { and loyalty. }\end{array}$ & $\begin{array}{l}\text { Questionnaire } \\
\text { was used for } \\
\text { collecting data } \\
\text { from } \\
\text { employees } \\
\text { working } \\
\text { in public and } \\
\text { private sector } \\
\text { organizations } \\
\text { in the UAE } \\
\text { during } \\
2011-2012\end{array}$ & $\begin{array}{l}\text { Nationality, } \\
\text { Employee } \\
\text { Loyalty. }\end{array}$ & $\begin{array}{l}\text { Arab expatriates } \\
\text { are characterized } \\
\text { by high levels of } \\
\text { loyalty compared to } \\
\text { civil servants. }\end{array}$ \\
\hline $\begin{array}{l}\text { Met and Ali } \\
(2014)\end{array}$ & $\begin{array}{l}\text { To investigate the } \\
\text { moderating effect } \\
\text { of demographic } \\
\text { factors (age, } \\
\text { gender, education } \\
\text { level, tenure, and } \\
\text { job level) on the } \\
\text { relationship } \\
\text { between monetary } \\
\text { motivation and } \\
\text { employees' } \\
\text { satisfaction and } \\
\text { loyalty. }\end{array}$ & $\begin{array}{l}\text { Data were } \\
\text { collected using } \\
\text { self-administer } \\
\text { ed survey } \\
\text { questionnaire } \\
\text { from } \quad 341 \\
\text { employees at } \\
\text { oil and gas } \\
\text { offshore } \\
\text { production } \\
\text { facilities of } \\
\text { selected } \\
\text { companies in } \\
\text { Malaysia. }\end{array}$ & $\begin{array}{l}\text { Age, } \\
\text { Gender, } \\
\text { Job Level, } \\
\text { Incentives, } \\
\text { Employee } \\
\text { Loyalty. }\end{array}$ & $\begin{array}{l}\text { The results showed } \\
\text { that there was a } \\
\text { significant } \\
\text { moderating effect } \\
\text { of age, gender, and } \\
\text { job level on the } \\
\text { relationship } \\
\text { between incentives } \\
\text { and employees' } \\
\text { satisfaction and } \\
\text { loyalty, while } \\
\text { education level did } \\
\text { not show any } \\
\text { significant } \\
\text { moderating effect. }\end{array}$ \\
\hline $\begin{array}{l}\text { Agyeman and } \\
\text { Ponniah, } \\
(2014)\end{array}$ & $\begin{array}{l}\text { To analyse the } \\
\text { various employee } \\
\text { demographic } \\
\text { characteristics and } \\
\text { their effects on } \\
\text { turnover and } \\
\text { retention in } \\
\text { MSMEs. }\end{array}$ & $\begin{array}{l}\text { Descriptive } \\
\text { research } \\
\text { approach has } \\
\text { been followed } \\
\text { and data was } \\
\text { collected from } \\
120 \text { MSMEs } \\
\text { randomly } \\
\text { selected. }\end{array}$ & $\begin{array}{l}\text { Working } \\
\text { Environment } \\
\text { Recognition, } \\
\text { Compensati } \\
\text { on, } \\
\text { Gender, } \\
\text { Age, } \\
\text { Education } \\
\text { Level, } \\
\text { Job } \\
\text { Experience, } \\
\text { Employee } \\
\text { Loyalty. }\end{array}$ & $\begin{array}{l}\text { - Different } \\
\text { demographic } \\
\text { characteristics as } \\
\text { gender, age, } \\
\text { education, and } \\
\text { years of service had } \\
\text { main effect on the } \\
\text { relationship } \\
\text { between working } \\
\text { environment, } \\
\text { recognition and } \\
\text { rewards, and } \\
\text { employee retention } \\
\text { and loyalty. }\end{array}$ \\
\hline
\end{tabular}




\begin{tabular}{|c|c|c|c|c|}
\hline $\begin{array}{ll}\text { Kaufman } & \text { et } \\
\text { al, }(2013) . & \end{array}$ & $\begin{array}{l}\text { To investigate the } \\
\text { effect } \\
\text { performance } \\
\text { recognition on } \\
\text { employee } \\
\text { engagement. }\end{array}$ & $\begin{array}{l}\text { Qualitative } \\
\text { research } \\
\text { included } \\
\text { interviews and } \\
\text { focus groups } \\
\text { involving over } \\
90 \text { participants } \\
\text { across varying } \\
\text { geographies, } \\
\text { cultures, and } \\
\text { ages. }\end{array}$ & $\begin{array}{l}\text { Gender, } \\
\text { Age, } \\
\text { Employee } \\
\text { Engagement. } \\
\text { Employee } \\
\text { Loyalty. }\end{array}$ & $\begin{array}{l}\text { There was a } \\
\text { statistically } \\
\text { significant } \\
\text { relationship } \\
\text { between employee } \\
\text { loyalty and } \\
\text { employee } \\
\text { recognition, and } \\
\text { that there were } \\
\text { differences in the } \\
\text { level of loyalty due } \\
\text { to gender, age, and } \\
\text { length of service. }\end{array}$ \\
\hline $\begin{array}{l}\text { Ineson et al. } \\
(2013)\end{array}$ & $\begin{array}{l}\text { To explore the } \\
\text { association } \\
\text { between } \\
\text { Hungarian } \\
\text { employees' job } \\
\text { satisfaction and } \\
\text { their loyalty to the } \\
\text { organisation. }\end{array}$ & $\begin{array}{l}\text { Questionnaire } \\
\text { was used to } \\
\text { collect data } \\
\text { from over } 600 \\
\text { hotel } \\
\text { employees } \\
\text { throughout } \\
\text { Hungary. }\end{array}$ & $\begin{array}{l}\text { Age, } \\
\text { Employee } \\
\text { Loyalty. }\end{array}$ & $\begin{array}{l}\text { A negative } \\
\text { correlation between } \\
\text { age and employee } \\
\text { loyalty. }\end{array}$ \\
\hline $\begin{array}{l}\text { Pandey and } \\
\text { Khare, (2012) }\end{array}$ & $\begin{array}{l}\text { To find the impact } \\
\text { of job satisfaction } \\
\text { and organizational } \\
\text { commitment on } \\
\text { employee loyalty. }\end{array}$ & $\begin{array}{l}\text { The study } \\
\text { questionnaire } \\
\text { survey was } \\
\text { used. }\end{array}$ & $\begin{array}{l}\text { Gender, } \\
\text { Age, } \\
\text { Employee } \\
\text { Loyalty. }\end{array}$ & $\begin{array}{l}\text { - No differences } \\
\text { between males and } \\
\text { females in loyalty. } \\
\text { - The higher the } \\
\text { employee's age, the } \\
\text { higher the level of } \\
\text { loyalty. }\end{array}$ \\
\hline $\begin{array}{l}\text { Zaidi and } \\
\text { Abbas (2011) }\end{array}$ & $\begin{array}{l}\text { To investigate the } \\
\text { impact of rewards } \\
\text { on the } \\
\text { motivational level } \\
\text { of employees of } \\
\text { telecommunicatio } \\
n \text { sector of } \\
\text { Pakistan. }\end{array}$ & $\begin{array}{l}\text { A total of } 292 \\
\text { questionnaires } \\
\text { were returned } \\
\text { fully complete }\end{array}$ & $\begin{array}{l}\text { Age, } \\
\text { Job } \\
\text { Experience, } \\
\text { Compensati } \\
\text { on, } \\
\text { Employee } \\
\text { Loyalty. }\end{array}$ & $\begin{array}{l}\text { - Employees who } \\
\text { were working for } \\
\text { less than one year } \\
\text { were significantly } \\
\text { more loyal and } \\
\text { satisfied with their } \\
\text { compensation than } \\
\text { those who were } \\
\text { working for one to } \\
\text { two years. } \\
\text { - Employees } 50 \\
\text { years and above } \\
\text { age group were } \\
\text { highly loyal and }\end{array}$ \\
\hline
\end{tabular}




\begin{tabular}{|c|c|c|c|c|}
\hline & & & & $\begin{array}{l}\text { satisfied with } \\
\text { compensation. }\end{array}$ \\
\hline $\begin{array}{l}\text { Bashir, } \\
\text { Jianqiao, } \\
\text { Zhao, } \\
\text { Ghazanfar, } \\
\text { and Khan, } \\
(2011)\end{array}$ & 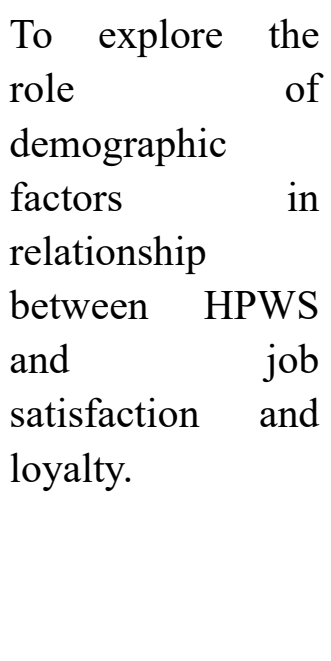 & $\begin{array}{l}\text { The data was } \\
\text { collected from } \\
674 \text { academic } \\
\text { faculties across } \\
23 \text { public } \\
\text { sector } \\
\text { universities. }\end{array}$ & $\begin{array}{l}\text { Recognition, } \\
\text { Compensati } \\
\text { on, } \\
\text { Age, } \\
\text { Employee } \\
\text { Loyalty. }\end{array}$ & $\begin{array}{l}\text { - Age group } 46-50 \\
\text { years was more } \\
\text { acceptance for job } \\
\text { rotation. } \\
\text { - Age group below } \\
30 \text { years was the } \\
\text { least loyal and } \\
\text { satisfied with } \\
\text { compensation while } \\
\text { age group } 46-50 \\
\text { years was the most } \\
\text { satisfied. }\end{array}$ \\
\hline
\end{tabular}

\section{Research Methodology}

A quantitative approach was used in this research to generate more in-depth and accurate information about the research topic (Halcomb \& Hickman, 2015). A random sample of 52 employees in the largest 14 logistics companies in Oman was selected to achieve the objective of this research. The primary source data used in this research was collected using questionnaire, which designed with the goals and objectives of research in mind. As the questionnaire consists of two sections. The first section is related to personal demographic data, including gender, age, nationality, job experience, and job level. While, the second section divided into eight (8) sub-sections, namely HRM practices (recognition, compensation, promotion, training, selective hiring, job rotation, and working environment) and employee loyalty, as every sub-section includes eight (8) questions.

The table 2 shows demographic characteristics of the respondents $(\mathrm{N}=52)$. The respondents were male $(71.2 \%, \mathrm{n}=37)$ and female $(28.8 \%, \mathrm{n}=15)$. Moreover, the age distribution of the respondents was $26.9 \%(n=14)$ from 18 to 29 years old, $32.7 \%(n=17)$ from 30 to 39 years old, $36.5 \%(n=19)$ from 40 to 49 years old, and $3.8 \%(n=2)$ above 50 years old. In addition, the nationality of the respondents was $71.2 \%(\mathrm{n}=37)$ local, and $28.8 \%(\mathrm{n}=$ expatriate $)$. Also, the job experience of the respondents was $28.8 \%(n=15)$ from 0 to $5,23.1 \%(n=12)$ from 6 to 10 , and $28.8 \%(n=15)$ more than 10 years. Finally, regarding the job level of the respondents, $19.2 \%(n=10)$ were at lower level, $48.1 \%(n=25)$ at middle level, and $32.7 \%$ $(n=17)$ at upper level. 


\section{II) Macrothink}

Table 2. Demographic characteristics of Respondents $(\mathrm{N}=52)$.

\begin{tabular}{ll}
\hline Variable & N (\%) \\
\hline
\end{tabular}

\section{Gender}

Male

$37(71.2 \%)$

Female

$15(28.8 \%)$

Age

18-29

$14(26.9 \%)$

30-39

$17(32.7 \%)$

40-49

$19(36.5 \%)$

$+50$

$2(3.8 \%)$

Nationality

Local

$37(71.2 \%)$

Expatriate

$15(28.8 \%)$

Job Experience

0-5

$15(28.8 \%)$

6-10

$12(23.1 \%)$

$>10$

$25(48.1 \%)$

Job Level

Lower Level (clerical and below)

$10(19.2 \%)$

Middle Level (executives)

$25(48.1 \%)$

Upper Level (managerial)

$17(32.7 \%)$

\subsection{Research Hypotheses}

Regression analysis was used to test the research hypotheses as shown in the tables below.

The first main hypothesis (H1): Gender does not influence the impact of on the relationship between HRM practices and employee loyalty.

Table 3. Results of the regression analysis - the impact of gender on the relationship between hrm practices and employee loyalty

\begin{tabular}{llllll}
\hline Model & Sum of Squares & df & Mean Square & F & Sig. \\
\hline Regression & 2.951 & 1 & 2.951 & 4.024 & $.055^{\mathrm{b}}$ \\
1 Residual & 36.662 & 50 & .733 & & \\
Total & 39.613 & 51 & & & \\
\hline
\end{tabular}




\section{Macrothink}

The Table 3 shows the simple regression model to represent the impact of gender on the relationship between HRM practices and employee loyalty. It is clear that Sig. value is 0.055 , which is higher than 0.05 , meaning that the null hypothesis is accepted and therefore, it can be inferred that gender had no impact on the relationship between HRM practices and employee loyalty in logistics companies.

The second main hypothesis (H2): Age does not influence the impact of on the relationship between HRM practices and employee loyalty.

Table 4. Results of the regression analysis - the impact of age on the relationship between hrm practices and employee loyalty

\begin{tabular}{llllll}
\hline Model & Sum of Squares & df & Mean Square & F & Sig. \\
\hline Regression & 1.544 & 1 & 1.544 & 2.028 & $.000^{\mathrm{b}}$ \\
1 Residual & 38.068 & 50 & .761 & & \\
Total & 39.613 & 51 & & & \\
\hline
\end{tabular}

The Table 4 shows the simple regression model to represent the impact of age on the relationship between HRM practices and employee loyalty. It is clear that Sig. value is 0.000 , which is less than 0.05 , meaning that the null hypothesis is rejected and therefore, it can be inferred that age had a significant impact on the relationship between HRM practices and employee loyalty in logistics companies.

The third main hypothesis (H3): Nationality does not influence the impact of on the relationship between HRM practices and employee loyalty.

Table 5. Results of the regression analysis - the impact of nationality on the relationship between HRM Practices and employee loyalty

\begin{tabular}{lllllll}
\hline Model & & Sum of Squares & df & Mean Square & F & Sig. \\
\hline \multirow{3}{*}{1} & Regression & .715 & 1 & .715 & .919 & $.000^{\mathrm{b}}$ \\
& Residual & 38.897 & 50 & .778 & & \\
& Total & 39.613 & 51 & & & \\
\hline
\end{tabular}

The Table 5 shows the simple regression model to represent the impact of nationality on the relationship between HRM practices and employee loyalty. It is clear that Sig. value is 0.000 , which is less than 0.05 , meaning that the null hypothesis is rejected and therefore, it can be inferred that nationality had a significant impact on the relationship between HRM practices and employee loyalty in logistics companies. 


\section{Al Macrothink}

Human Resource Research

ISSN 1948-5441

2020, Vol. 4, No. 1

The fourth main hypothesis (H4): Job experience does not influence the impact of on the relationship between HRM practices and employee loyalty.

Table 6. Results of the regression analysis - the impact of job experience on the relationship between HRM practices and employee loyalty

\begin{tabular}{|c|c|c|c|c|c|c|}
\hline Model & & Sum of Squares & df & Mean Square & $\mathrm{F}$ & Sig. \\
\hline \multirow{3}{*}{1} & Regression & .223 & 1 & .223 & .283 & $.000^{\mathrm{b}}$ \\
\hline & Residual & 39.390 & 50 & .788 & & \\
\hline & Total & 39.613 & 51 & & & \\
\hline
\end{tabular}

The Table 6 shows the simple regression model to represent the impact of job experience on the relationship between HRM practices and employee loyalty. It is clear that Sig. value is 0.000 , which is less than 0.05 , meaning that the null hypothesis is rejected and therefore, it can be inferred that job experience had a significant impact on the relationship between HRM practices and employee loyalty in logistics companies.

The fifth main hypothesis (H5): Job level does not influence the impact of on the relationship between HRM practices and employee loyalty.

Table 7. Results of the regression analysis - the impact of job level on the relationship between HRM practices and employee loyalty

\begin{tabular}{lllllll}
\hline Model & & \multicolumn{2}{l}{ Sum of Squares df } & Mean Square & F & Sig. \\
\hline \multirow{3}{*}{1} & Regression & 1.480 & 1 & 1.480 & 1.941 & $.000^{\mathrm{b}}$ \\
& Residual & 38.132 & 50 & .763 & & \\
& Total & 39.613 & 51 & & & \\
\hline
\end{tabular}

The Table 7 shows the simple regression model to represent the impact of job level on the relationship between HRM practices and employee loyalty. It is clear that Sig. value is 0.000 , which is less than 0.05 , meaning that the null hypothesis is rejected and therefore, it can be inferred that job level had a significant impact on the relationship between HRM practices and employee loyalty in logistics companies.

\section{Recommendation and Conclusion}

This paper aims to ascertain theoretically and empirically if there is any impact of demographic variables (gender, age, nationality, job experience, and job level) on the relationship between HRM best practices and employee loyalty in the Omani Logistic Sector. This paper discusses literature review as a methodology for achieving research objectives. The majority of prior literature illustrated that no differences between males and females in 
loyalty, the older employees are more loyal than younger employees, and citizens are more loyal than expat. In addition, literature explained that the longer the employee's years of experience, the more loyalty to the organization as well as the higher the level of the employees' career, the more loyal they have. To check the results achieved in meta-analysis review, a quantitative approach was adopted through the questionnaires that were distributed to 52 employees in the largest 14 logistics companies in Oman, as the regression analysis on SPSS was used to find whether there is any impact of demographic variables on the relationship between HRM practices and employee loyalty. The results illustrated that gender had no impact on the relationship between HRM practices and employee loyalty. While, age, nationality, job experience, and job level had a significant impact on the relationship between HRM practices and employee loyalty.

The outcomes of this research may be the starting point for many future research that are interested in the moderating effect of demographic variables on the relationship between HRM practices and employee loyalty in Oman. Also, many demographic variables that have not been discussed in this research can be considered, which have a significant impact such as level of education. Moreover, future researchers can benefit from the idea of this study by applying it to other sectors such as telecommunications, banks, etc. Finally, future researchers can use other methods such as the qualitative approach and case study, then making a comparison between the results.

\section{References}

Abidi, O., Halil, Z. A. I. M., Youssef, D., Habibniya, H., \& Baran, A. (2017). Diversity management and its impact on HRM Practices: Evidence from Kuwaiti companies. Eurasian Journal of Business and Economics, 10(20), 71-88. https://doi.org/10.17015/ejbe.2017.020. 05

Agyeman, C. M., \& Ponniah, V. M. (2014). Employee demographic characteristics and their effects on turnover and retention in MSMEs. International Journal of Recent Advances in Organizational Behaviour and Decision Sciences, 1(1), 12-29.

Ahammad, T. (2017). Personnel Management to Human Resource Management (HRM): How HRM Functions? Journal of Modern Accounting and Auditing, 13(9), 412-420. https://doi.org/10.17265/1548-6583/2017.09.004

Aityan, S. K., \& Gupta, T. K. P. (2012). Challenges of employee loyalty in corporate America. Business and Economics Journal.

Al Saddi, M. F. (2016). The Need of Incentives Program for Employees of the Ministry of Education in Sultanate of Oman. International Journal of Business and Social Science, 7(12).

Al-Belushi, F., \& Khan, F. (2017). Impact of Monetary Incentives on Employee's Motivation: Shinas College of Technology, Oman-A Case Study. International Journal of Management, Innovation \& Entrepreneurial Research, 3(1), 01-11. https://doi.org/10.18510/ijmier.2017.311

Alfes, K., Shantz, A. D., Truss, C., \& Soane, E. C. (2013). The link between perceived human resource management practices, engagement and employee behaviour: a moderated 


\section{Macrothink}

Human Resource Research

ISSN 1948-5441

2020, Vol. 4, No. 1

mediation model. The international journal of human resource management, 24(2), 330-351. https://doi.org/10.1080/09585192.2012.679950

Alshuaibia, A. S. I., \& Shamsudinb, F. M. (2016). The Role of Human Resource Management Practices in Enhancing Internal Branding. International Soft Science Conference. https://doi.org/10.15405/epsbs.2016.08.85

Armstrong, A., Francis, R., \& Grow, H. (2017). Ethical issues in the employment of expatriate leaders in corporations. Journal of Economic and Social Development, 4(1), 71-80.

Armstrong, M. and Taylor, S. (2014). Armstrong's handbook of human resource management practice. Kogan Page Publishers.

Bashir, M., Jianqiao, L., Zhao, J., Ghazanfar, F., \& Khan, M. M. (2011). The role of demographic factors in the relationship between high performance work system and job satisfaction: A multidimensional approach. International Journal of Business and Social Science, 2(18).

Brewster, C., Gooderham, P. N., \& Mayrhofer, W. (2016). Human resource management: the promise, the performance, the consequences. Journal of Organizational Effectiveness: People and Performance, 3(2), 181-190. https://doi.org/10.1108/JOEPP-03-2016-0024

Buntak, K., \& Drožđek, I. (2016). Parameters Influencing Employee Loyalty. 1st International conference on Quality of Life June 2016, Centre for Quality, Faculty of Engineering, University of Kragujevac.

Chyn, G. H., \& Kaliannan, M. (2011). Human resource management practices in logistic service provider industry: A case study. Interdisciplinary Journal of Contemporary Research in Business, 2(9), 32-44.

Donovan, J. J., Dwight, S. A., \& Schneider, D. (2014). The impact of applicant faking on selection measures, hiring decisions, and employee performance. Journal of Business and Psychology, 29(3), 479-493. https://doi.org/10.1007/s10869-013-9318-5

Fairlie, R. W., \& Miranda, J. (2017). Taking the leap: The determinants of entrepreneurs hiring their first employee. Journal of Economics \& Management Strategy, 26(1), 3-34. https://doi.org/10.1111/jems.12176

Geevarghese, Nirmalraj, R. J. T., Seeram, H., Veena, S., \& James, B. (2018). Effect of Age on Employees' Loyalty: a Study among the Executives' of a Large Scale Public Sector Manufacturing Industry across India. International Journal of Engineering \& Technology, 7(3.1), 9-12. https://doi.org/10.14419/ijet.v7i3.1.16785

Halcomb, E., \& Hickman, L. (2015). Mixed methods research. Nursing Standard (2014+), 29(32), 41. https://doi.org/10.7748/ns.29.32.41.e8858

Harrison, K. (2013). Why employee recognition is so important. Cutting Edge PR. Harting, D.(2010). Employees your most valuable asset. Retrieved January, 3.

Hassan, M., Hassan, S., Khan, M. F. A., \& Iqbal, A. (2013). Impact of HR practices on 
employee satisfaction and employee loyalty: An empirical study of government owned public sector banks of Pakistan. Middle-East Journal of Scientific Research, 16(1), 1-8.

Hassan, S. (2016). Impact of HRM practices on employee's performance. International Journal of Academic Research in Accounting, Finance and Management Sciences, 6(1), 15-22. https://doi.org/10.6007/IJARAFMS/v6-i1/1951

Hill, N., \& Alexander, J. (2017). The handbook of customer satisfaction and loyalty measurement. Routledge. https://doi.org/10.4324/9781315239279

Hon, A. H., Chan, W. W., \& Lu, L. (2013). Overcoming work-related stress and promoting employee creativity in hotel industry: The role of task feedback from supervisor. International Journal of Hospitality Management, 33, 416-424. https://doi.org/10.1016/j.ijhm. 2012.11.001

Ibrahim, M., \& Al Falasi, S. (2014). Employee loyalty and engagement in UAE public sector. Employee Relations, 36(5), 562-582. https://doi.org/10.1108/ER-07-2013-0098

Ibrar, M., \& Khan, O. (2015). The impact of reward on employee performance (a case study of Malakand Private School). International Letters of Social and Humanistic Sciences, 52, 95-103. https://doi.org/10.18052/www.scipress.com/ILSHS.51.95

Ineson, E. M., Benke, E., \& László, J. (2013). Employee loyalty in Hungarian hotels. International Journal of Hospitality Management, 32, 31-39. https://doi.org/10.1016/j.ijhm. 2012.04.001

Iqbal, A., Tufail, M., \& Lodhi, R. (2015). Employee loyalty and organizational commitment in Pakistani organizations. Global Journal of Human Resource Management, 3(1), 1-11.

Ismail, H. N., \& Nakkache, L. (2015). Gender differences at work: Experiencing human resource management policies in Lebanese firms. Global Business Review, 16(6), 907-919. https://doi.org/10.1177/0972150915597592

Jureidini, R. (2016). Ways forward in recruitment of low-skilled migrant workers in the Asia-Arab states corridor. ILO White Paper. International Labour Organization, ILO Regional Office for the Arab States.

Kabak, K. E., Şen, A., Göçer, K., Küçüksöylemez, S., \& Tuncer, G. (2014). Strategies for employee job satisfaction: A case of service sector. Procedia-Social and Behavioural Sciences, 150, 1167-1176. https://doi.org/10.1016/j.sbspro.2014.09.132

Kamnerdkarn, S. (2010). Factors that Affect Employment Loyalty to an Organization: A Study of an Undergarment Factory in Nakhonpathom. Language Institute, Thammasat University.

Kathure, D. O. R. E. E. N. (2014). Influence of non-financial rewards on employee commitment at kenya tea development agency. University of Nairobi.

Kato, T., \& Kodama, N. (2017). Women in the workplace and management practices: Theory and evidence. IZA DP, No. 10788. https://doi.org/10.1093/oxfordhb/9780190628963.013.33 


\section{Ml Macrothink}

Human Resource Research

ISSN 1948-5441

2020, Vol. 4, No. 1

Katou, A. A., Budhwar, P. S., Woldu, H., \& Basit Al-Hamadi, A. (2010). Influence of ethical beliefs, national culture and institutions on preferences for HRM in Oman. Personnel Review, 39(6), 728-745. https://doi.org/10.1108/00483481011075585

Kaufman, T., Chapman, T., \& Allen, J. (2013). The effect of performance recognition on employee engagement. Cicero Group.

Kee, H. P., Low, P. W., Ooi, C. K., Sam, M. K., \& Teng, C. H. (2012). A study on the impacts towards the loyalty of the employee among the back of house staffs in hotel industry (Doctoral dissertation, UTAR).

Khuong, M. N., \& Tien, B. D. (2013). Factors influencing employee loyalty directly and indirectly through job satisfaction-A study of banking sector in Ho Chi Minh City. International Journal of current research and academic review, 1(4), 81-95.

Klopotan, I., Buntak, K., \& Drožđek, I. (2016). Employee loyalty: differences between genders and the public and the private sector. Interdisciplinary Description of Complex Systems: INDECS, 14(3), 303-313. https://doi.org/10.7906/indecs.14.3.3

Kooij, D. T., Guest, D. E., Clinton, M., Knight, T., Jansen, P. G., \& Dikkers, J. S. (2013). How the impact of HR practices on employee well-being and performance changes with age. Human Resource Management Journal, 23(1), 18-35. https://oi.org/10.1111/1748-8583. 12000

Kossivi, B., Xu, M., \& Kalgora, B. (2016). Study on determining factors of employee retention. Open Journal of Social Sciences, 4(05), 261. https://doi.org/10.4236/jss.2016. 45029

Maimako, L. B., \& Bambale, A. J. (2016). Human Resource Management Practices and Employee Job Satisfaction in Kano State owned Universities: A Conceptual Model. Journal of Marketing and Management, 7(2), 1.

Marcus, A., and Gopinath, N. M. (2017). Impact of the demographic variables on the employee engagement-an analysis. Ictact Journal on Management Studies, 3(2), 502-510. https://doi.org/10.21917/ijms.2017.0068

Menon, S. T. (2012). Human resource practices, supply chain performance, and wellbeing. International Journal of Manpower, 33(7), 769-785. https://doi.org/10.1108/014377212112 68311

Met, M., \& Ali, I. (2014). Investigating the moderating effect of demographic factors on the relationship between monetary motivation and employees' job satisfaction at oil and gas offshore production facilities in Malaysia. International Review of Management and Business Research, 3(2), 788-818.

Mira, M., Choong, Y., \& Thim, C. (2019). The effect of HRM practices and employees' job satisfaction on employee performance. Management Science Letters, 9(6), 771-786. https://doi.org/10.5267/j.msl.2019.3.011 


\section{I Macrothink}

Human Resource Research

ISSN 1948-5441 2020, Vol. 4, No. 1

Nisar, Q. A., Uzair, M., Razzaq, W., \& Sarfraz, M. (2017). Impact of HR Practices on Employee loyalty and commitment: Mediating role of Job satisfaction. International Journal of Management Excellence, 9(2), 1067-1073. https://doi.org/10.17722/ijme.v9i2.347

Pandey, C., \& Khare, R. (2012). Impact of job satisfaction and organizational commitment on employee loyalty. International Journal of Social Science and Interdisciplinary Research, $1(8), 26-41$.

Porkodi, S., \& Jahan, U. (2015). Bank Employees' Expectations of Training Programmes in Oman-An Exploratory Study. Research Journal of Commerce \& Behavioral Science, 04(03).

Prabhakar, A. (2016). Analysis of high job satisfaction relationship with employee loyalty in context to workplace environment. IJAR, 2(4), 640-643.

Schlechter, A., Thompson, N. C., \& Bussin, M. (2015). Attractiveness of non-financial rewards for prospective knowledge workers: An experimental investigation. Employee Relations, 37(3), 274-295. https://doi.org/10.1108/ER-06-2014-0077

Sekyi, E., Boakye, N., \& Ankumah, F. (2016). Analysing the Factors Influencing Employee Loyalty in the Hotel Industry in Takoradi, Ghana. Journal of Tourism, Hospitality and Sports, 18.

Shonubi, O. A., Abdullah, N., Hashim, R., \& Ab Hamid, N. B. (2016). Recognition and Appreciation and the Moderating Role of Self-esteem on Job Satisfaction and Performance among IT Employees in Melaka. Journal of Health Science, 4, 221-227. https://doi.org/ $10.17265 / 2328-7136 / 2016.05 .001$

Sila, E., \& Širok, K. (2018). The Importance of Employee Satisfaction: A Case Study of a Transportation and Logistics Service Company. Management (18544223), 13(2). https://doi.org/10.26493/1854-4231.13.111-136

Singh, N. R., \& Kassa. (2016). The Impact of Human Resource Management Practice on Organizational Performance - A Study on DebreBrehan University. International Journal of Recent Advances in Organizational Behaviour and Decision Sciences (IJRAOB), 1(1), 643-662.

Singh, P., \& Twalo, T. (2015). Mismanaging unethical behaviour in the workplace. Journal of Applied Business Research, 31(2), 515. https://doi.org/10.19030/jabr.v31i2.9150

Strenitzerová, M., \& Achimský, K. (2019). Employee Satisfaction and Loyalty as a Part of Sustainable Human Resource Management in Postal Sector. Sustainability, 11(17), 4591. https://doi.org/10.3390/su11174591

Swailes, S., \& Al Fahdi, S. (2011). Voluntary turnover in the Omani public sector: an Islamic values perspective. International Journal of Public Administration, 34(10), 682-692. https://doi.org/10.1080/01900692.2011.583770

Tomic, I., Tesic, Z., Kuzmanovic, B., \& Tomic, M. (2018). An empirical study of employee loyalty, service quality, cost reduction and company performance. Economic 


\section{Macrothink}

Research-EkonomskaIstraživanja, 31(1), 827-846.

Truxillo, D. M., Cadiz, D. M., \& Rineer, J. R. (2014). The aging workforce: Implications for human resource management research and practice. Oxford handbooks online: Business \& management. Advance online publication. https://doi.org/10.1093/oxfordhb/9780199935406. 013.004

Vanhala, M., \& Ritala, P. (2016). HRM practices, impersonal trust and organizational innovativeness. Journal of Managerial Psychology, 31(1), 95-109. https://doi.org/10.1108/ JMP-03-2013-0084

Vinayan, J. (2015). Vulnerability of HR Systems and Practices to Corruption: A Review and Research Agenda. Editorial Team, 7(1), 25.

Wallenburg, C., Cahill, D. L., Goldsby, T. J., \& Knemeyer, A. M. (2010). Logistics outsourcing performance and loyalty behavior: Comparisons between Germany and the United States. International Journal of Physical Distribution \& Logistics Management, 40(7), 579-602. https://doi.org/10.1108/09600031011072019

Waqas, A., Bashir, U., Sattar, M. F., Abdullah, H. M., Hussain, I., Anjum, W., ... Arshad, R. (2014). Factors influencing job satisfaction and its impact on job loyalty. International Journal of Learning and Development, 4(2), 141-161. https://doi.org/10.5296/ijld.v4i2.6095

Yaghi, A., \& Aljaidi, N. (2014). Examining organizational commitment among national and expatriate employees in the private and public sectors in United Arab Emirates. International Journal of Public Administration, 37(12), 801-811. https://doi.org/10.1080/01900692.2014. 907314

Zaidi, F. B., \& Abbas, Z. (2011). A study on the impact of rewards on employee motivation in the telecommunication sector of Pakistan. Interdisciplinary journal of contemporary research in business, 3(3), 978-998.

\section{Copyright Disclaimer}

Copyright for this article is retained by the author(s), with first publication rights granted to the journal.

This is an open-access article distributed under the terms and conditions of the Creative Commons Attribution license (http://creativecommons.org/licenses/by/3.0/). 